\title{
EVALUATION OF THE EFFICIENCY OF RESEARCH AND DEVELOPMENT IN EU COUNTRIES
}

\author{
[Hodnocení efektivity výzkumu a vývoje v zemích EU] \\ Martina Halásková ${ }^{1}$, Blanka Bazsová ${ }^{2}$ \\ ${ }^{I}$ Vysoká škola báňská-Technická univerzita Ostrava, Ekonomická fakulta, Sokolská 3370121 Ostrava \\ Email:martina.halaskoval@vsb.cz \\ ${ }^{2}$ Vysoká škola báňská-Technická univerzita Ostrava, Ekonomická fakulta, Sokolská 33, 70121 Ostrava \\ Email:blanka.bazsova@vsb.cz
}

\begin{abstract}
This paper deals with the efficiency evaluation of research and development in EU (28) member states. More specifically, it provides an evaluation of human resources (researchers) and total expenditure on research and development (R\&D) with respect to the achieved results (the number of publications, citable documents and patent applications to the European Patent Office). The efficiency is assessed by means of a multi-criteria method of DEA-data envelopment analysis-namely the CCR method of an input-oriented model, which enables determining the amount of inputs (expenditures on $R \& D$ and researchers) with the maximum output that should be generated in order for a country to be efficient. The aim of the paper is to identify the efficiency of scientific and research activities of the EU member states, on the basis of a quantitative approach by use of the selected R\&D indicators. The results proved differences in scientific and research activities in the countries with the application of the DEA method. R\&D efficiency in EU countries is evaluated with more indicators (including the $\mathrm{H}$-index). In most cases, the application of another output makes no difference to the position of the countries in terms of their efficiency.
\end{abstract}

Keywords: DEA, development, efficiency, EU Countries, evaluation, model CCR, performance, research.

JEL classification: $\mathrm{C} 67, \mathrm{C} 82, \mathrm{O} 32$

Doručeno redakci: 15.4.2016; Recenzováno: 4.5.2016; 23.5.2016; 4.7.2016; Schváleno k publikování: 30.11 .2016

\section{Introduction}

Research and development (R\&D) play a key role in the generation of new knowledge, products and technological processes, which are an indispensable condition for a stable and sustainable economic growth of society. Research is a key factor in the development of every country. It is an intentional, systematic activity based on techniques of data gathering. The level and intensity of research, development and innovation are closely related to the economic level of a given country, the dynamics of economic development, as well as the creation of added value and employment. At the European level, research suffers from a variety of shortcomings. These are: a distortion of activities, an isolated nature of national systems of research, low financing from public and private sources, and low investments in the development of knowledge (Becker 2015; David, Hall and Toole 2000). "Efficiency evaluation in terms of the differences between countries and regions should be measured through a complex of economic, social and environmental criteria that identify imbalanced areas that cause the main disparities" (Staníčková and Melecký 2012, p. 146). Efficiency of the R\&D sector in EU countries at the regional level is further analysed in research by Aristovnik (2014). In several papers, e.g. Bojnec and Ferto (2014); Lee, Park and Choi (2009); Szarowská (2016), attention is paid to current issues in $R \& D$ associated with trends in national $R \& D$ policies, reforms and potential for public as well as private financing of $R \& D$. 
A vital condition for the fulfilment of the Europe 2020 strategy in R\&D are financial capabilities of the countries. The member states should begin investing $3 \%$ of their GDP in R\&D by no later than 2020 (1\% from public resources, $2 \%$ from resources from the private sector), which should generate 3.7 million new jobs and contribute to the increase of the annual GDP by almost 800 billion Euro till 2025 (European Commission 2010, 2016). If Europe aims to become a more competitive knowledge-based economy, it will have to improve not only the generation of knowledge but also its dissemination and application. For the sake of the evaluation of competitiveness, it is necessary to observe the individual features of the national innovation system as well as the relation and efficiency of these ties (Halásková and Halásková 2015).

This paper aims to identify the efficiency of scientific and research activities of the EU member states, on the basis of a quantitative approach, using the selected R\&D indicators. It focuses on the evaluation of R\&D efficiency by selected indicators in EU countries, using the DEA method, with the input information of total expenditures on R\&D in \% of GDP (GERD) and the number of researchers, and the output of the number of publications, cited documents, patent applications to the EPO.

The paper comprises five chapters. It is divided into the theoretical and empirical part. The introduction to $\mathrm{R} \& \mathrm{D}$ at the European level concentrates on the theoretical basis for the assessment of R\&D efficiency and research carried out by means of the DEA method. Moreover, a methodology is worked out, including the process of tackling the issue, the description of the method used and data for the R\&D efficiency assessment. The empirical part provides a summary of the R\&D efficiency assessment results in EU countries on the basis of the selected input and output, using the DEA method, including the discussion. The selected $\mathrm{R} \& \mathrm{D}$ indicators are also evaluated by means of correlation analysis. The last section provides the conclusion, with comments on the main results as well as topics for further research.

\section{Theoretical background and literature review}

Research, development and innovation policy, and the European Research Area are topics discussed in the paper referred to as European Science and Technology Policy (Delanghe, Muldur and Soete 2009). This innovative book focuses on the most important concept underpinning current European Union research policy. It describes the history and concept of the European Research Area (ERA), it analyses some of the underlying assumptions, assesses some of its achievements, and takes a brief look at its future. European Science and Technology Policy deals with the notion of the ERA, a coordinated and effective European Research Area, the successful achievement of which is the main objective of the EU research policy under the Lisbon Treaty. The book demonstrates that almost ten years after the formal launch of the ERA concept, little top-down progress seems to have been made in terms of achieving better governance of the European research landscape. However, tangible bottom-up progress has been made towards harmonizing research beyond the existing uncoordinated national, intergovernmental and supranational policy schemes. Given the current ongoing ERA debate, this timely publication will be an invaluable tool for technology and innovation policymakers and practitioners in Europe.

In relation to the output of $R \& D$, attention is paid not only to their quantity but also quality. $R \& D$ effectiveness and efficiency must not be omitted in this respect. Efficiency is generally defined as a ratio of inputs and outputs of the production unit, and it also serves as a means to benchmarking. Still, the size of production units is not exactly defined, it is therefore assessed at different levels of economy and in various areas. The evaluation of efficiency and 
performance of production units is a topical issue both at the microeconomic as well as the macroeconomic level (Jablonský and Dlouhý 2004). With respect to their scarcity, the allocation of available resources needs to be observed. The observation of economy, effectiveness and efficiency plays a key role in this process, which are also the three basic indicators of efficiency, the $3 \mathrm{E}$. This approach was developed on the basis of the Value-forMoney method (VFM). As some authors state (e.g. Ochrana 2005), economy can be understood as achieving defined goals with minimum costs.

Wagner (2009, p. 18) states that, in contrast to efficiency, effectiveness is determined without reference to costs and, whereas efficiency means "doing the thing right", mentioning performance as the way a defined activity is carried out. Effectiveness means "doing the right thing" and indicates the performance in the sense of choice of the activity carried out. According to Sherman and Zhu (2006) or Ekinci and Ön (2015), efficiency can be simply defined as the ratio of output to input. More output per a unit of input reflects a relatively higher efficiency. If the largest possible output per a unit of input is achieved, a state of absolute or optimum efficiency has been achieved and it is not possible to become more efficient without new technology or other changes to the production process. The definition of efficiency is divided into three features: technical, economic and allocative efficiency. Technical efficiency deals with the relation between inputs and outputs (Hawdon 2003). According to Sherman and Zhu (2006) economic efficiency deals with the same situation as technical efficiency, but from the perspective of price. When there are multiple inputs and the reason for inefficiency can be related to the mix of inputs used to produce the mix of outputs, it is called allocative efficiency. Non-parametric methods evaluate technical (technological) efficiency focusing on the level of inputs and outputs. Minimizing inputs at a given level of outputs or vice versa leads to being technically efficiency.

As Vincova (2005) states, the most commonly used technique to measure technical efficiency is Data Envelopment Analysis (DEA). In parametric methods, economic efficiency is achieved by choosing a significant volume and structure of inputs and outputs in order to minimize costs or maximize profit. Economic efficiency requires both technical efficiency and efficient allocation. For technical efficiency one only needs input and output data while for economic efficiency price data are also needed. Among the parametric methods, the most widely used is Stochastic Frontier Approach (SFA). Assessment and measuring of efficiency in R\&D by means of the DEA methods is becoming a topical area of interest for numerous authors and research studies not only in the European context. Roman (2010) in his study evaluates regional efficiency based on R\&D indicators in Romania and Bulgaria. The paper analyzes research efficiency at the regional level for NUTS2 regions from Romania and Bulgaria between 2003 and 2005. Aristovnik (2014) applies a non-parametric approach, i.e. data envelopment analysis (DEA), to assess the relative technical efficiency of R\&D activities across the selected EU (NUTS-2) regions. The empirical analysis integrates available inputs (R\&D expenditures, researchers and employment in high-tech sectors) and outputs (patent and high-tech patent applications) over the 2005-2010 period. The same author see Aristovnik (2012) deals also with measuring relative efficiency while making use of the DEA method in two areas of the public sector (R\&D and Education) in the new EU member states in comparison to the selected EU (plus Croatia) and OECD countries. "The paper attempts to measure the relative efficiency in utilizing public education and R\&D expenditures. Cyprus and Hungary dominate the field of the $R \& D$ sector, although for different reasons. The empirical results also suggest that, in general, new EU member states lag well behind in the R\&D efficiency measures" (Aristovnik, 2012, p. 832). 
Other authors e.g. Ekinci and Ön (2015) focus on R\&D efficiency and comparisons in EU countries as well, using the DEA method in their study. The study attempts to analyse R\&D efficiency in EU countries on the basis of a whole host of input and output indicators. Other authors, such as Hudec and Prochádzková (2013), focus on the relative efficiency of knowledge innovation processes in EU countries. In the article, 19 countries of the European Union are studied, with a particular focus on the efficiency of innovation processes in the Visegrad countries, which joined the EU in the same year 2004. Hudec and Prochádzková (2013, p. 145) state: "The DEA method shows that majority of countries reach a higher relative innovation efficiency in knowledge commercialization than in knowledge production and the most important slacks can be found in research and development financing. Surprisingly, they are also in a group of high performers in bringing innovations to market, although they show substantial deficiencies in generating patents and international scientific papers".

\section{Methodology and data}

In EU countries, the selected $R \& D$ indicators are assessed on the basis of input (total expenditures on R\&D in \% of GDP (GERD), the number of researchers) and output (the number of publications, cited documents, patent applications to the EPO) in 2013. Efficiency R\&D, based on the selected indicators, was evaluated in 2013 using the DEA method. As a next step, R\&D efficiency was evaluated and compared in EU countries in years 2012 and 2013 with a larger number of outputs (H-index - Hirsch index - was added). Hirsch index represents the volume of reactions on scientific papers published by a single scientist. It is a comprehensive indicator of citing rate as opposed to a mere citing response of a particular paper. The selected R\&D indicators (inputs and outputs) were evaluated by means of correlation analysis. The authors strive for a current view on the issue in question. With regard to this fact, the latest available data on EU countries' patent applications to the EPO were available up to 2013. For the use of the DEA method, also data from 2013 were used for the remaining R\&D indicators observed. Results of R\&D efficiency in EU countries in year 2013 were further compared with 2012. Statistical data from Eurostat and the Scimago agency database were used in the processing stage. The set of $28 \mathrm{EU}$ countries, chosen on the basis of a deliberate selection: (Belgium- BE, Bulgaria-BG, Czech Republic-CZ, Denmark-DK, Germany-DE, Estonia-EE, Ireland-IE, Greece-EL, Spain-ES, France-FR, Croatia-HR, Italy-IT, Cyprus-CY, Latvia-LV, Lithuania-LT, Luxembourg-LU, Hungary-HU, Malta-MT, Netherlands-NL, Austria-AT, Poland-PL, Portugal-PT, Romania-RO, Slovenia-SI, Slovakia-SK, Finland-FI, Sweden-SE, United Kingdom-UK).

The paper focuses on R\&D efficiency in EU countries and the fact which countries fully exploit their potential in R\&D and which fail to do so. To achieve a balanced development, countries, particularly those ineffective in science and research activities and in exploiting their resources, should confront their results with their national R\&D strategy, proposing a way of improving the unsatisfactory state. R\&D efficiency in EU countries is arrived through the DEA (Data Envelopment Analysis) method, namely the input-oriented CCR model. DEA is a method of multi-criterion assessment for assessing the efficiency of production units (DMU - Decision Making Units) which use an identical input to produce an identical output (Toloo 2015; Charnes, Cooper and Rhodes 1978). DMUs can be banks, department stores, supermarkets, hospitals, public libraries, etc (Cooper, Seiford and Tone 2007). The efficiency of production units is based on a mathematical expression of efficiency.

Efficient units are those that reach the maximum value (Toloo 2015). As DMU makes use of a variety of inputs in production, it generates different outputs, and each of these inputs and outputs differs in the value. If we indicate inputs as the variable $x_{1}, \ldots x_{m}$ and outputs as the 
variable $y_{1}, \ldots y_{n}$, for DMUs whose amount is $j=1, \ldots n$, then the calculation of the production units' efficiency is:

$$
\theta_{k}=\frac{\sum_{j=1}^{n} u_{j} y_{j k}}{\sum_{i=1}^{m} v_{i} x_{i k}}
$$

with $u$ and $v$ expressing the weights of inputs and outputs, where $k$ expresses the efficiency of the $k$-th DMU. Efficiency can reach values within the interval $\langle 0.1\rangle$. The production unit is efficient if the ratio result equals 1.0000 . The more the value approaches 0 . the less the country is efficient in its use of resources. The efficiency assessment of production units can also be visualized graphically. If a unit is ineffective, is lies on the efficiency frontier (Jablonský and Dlouhý 2004). That means it makes an efficient use of input which is transformed into the required output. If it lies outside the frontier, it is inefficient. Charnes, Cooper and Rhodes (1978) formulated a linear-programming model to calculate the efficiency. In calculating the efficiency, the objective function equals the maximum of the ratio of weighed output and weighed input. This model was adjusted to a non-linear, and extended by a non-convex approach and named the CCR model (Toloo 2015). Two groups of model are distinguished input and output oriented models. An input oriented model is based on maximized inputs DMU intends to reach. An output-oriented model is based on an effort to minimize inputs in the objective function. This is connected with the decision of the given DMU management regarding their preferences in case they should like to move the DMU to the efficiency frontier. In such a case they have two alternatives: either reducing the number of inputs used, or increasing outputs. Should we want to influence input and maximize output, the input oriented model needs to be used (CCR) for $j=1 \ldots, n$ DMU (Decision Making Units). Charnes, Cooper and Rhodes (1978) devised the following input-oriented CCR model:

$$
\begin{aligned}
& \max \theta=\sum_{r=1}^{s} u_{r} y_{r 0} \\
& \sum_{i=1}^{m} v_{i} x_{i 0}=1 \\
& \sum_{r=1}^{s} u_{r} \times y_{r j}-\sum_{i=1}^{m} v_{i} x_{i j} \leq 0, \text { where } j=1, \ldots, \mathrm{n} \\
& v_{i}, \geq 0 \quad i=1, \ldots, m \\
& u_{r} \geq 0 \quad r=1, \ldots, s
\end{aligned}
$$

Variables $u$ and $v$ are unknown in this model values which are calculated (expressed) by means of the DEA CCR model (Toloo 2015). The weights must not be negative. The CCR model enables the number of inputs to be applied by an inefficient DMU unit to become efficient. The calculated weights are used to define the number of units by which inputs must be reduced or outputs increased.

\section{Results and discussion}

This part presents the results of the R\&D efficiency assessment of the EU countries on the basis of the selected indicators by means of the DEA method and correlation analysis.

\subsection{R\&D efficiency evaluation of the EU countries}

The R\&D efficiency assessment of the EU countries was carried out on the basis of the selected R\&D indicators in 2013. The R\&D efficiency assessment using the DEA method aims to analyse the basis of the national R\&D strategy of EU countries in the context of consumed expenditures and the number of researchers, in comparison to output, i.e. the number of publications, cited documents and patent applications to the EPO. Based on the results yielded, suggestions for low R\&D efficient countries as to how to become more effective were offered. 
Figure 1 illustrates an example of the CCR model of production units (DMU), introduced by the individual countries of the EU (28). The production units consume identical input and produce identical output. In this particular case, two inputs: R\&D expenditures and the number of $R \& D$ researchers are necessary. The system produces three outputs, comprising the number of publications, the number of cited documents and the number of patent applications to the European Patent Office (EPO).

A strong mutual dependency between total expenditures on $R \& D$ and the number of publications can be observed in EU countries, similarly also between total expenditures and patent applications to the EPO. Another correlation between input and output in indicators of R\&D in EU countries can be viewed between the number of researchers and publications, as documented by research using the correlation analysis (Halásková and Halásková 2015; Halásková and Bednár 2016). Relations between the inputs and outputs in the present research are dealt with in section 3.2.

Figure 1: Efficiency model of EU (28) member states, based on R\&D input and output

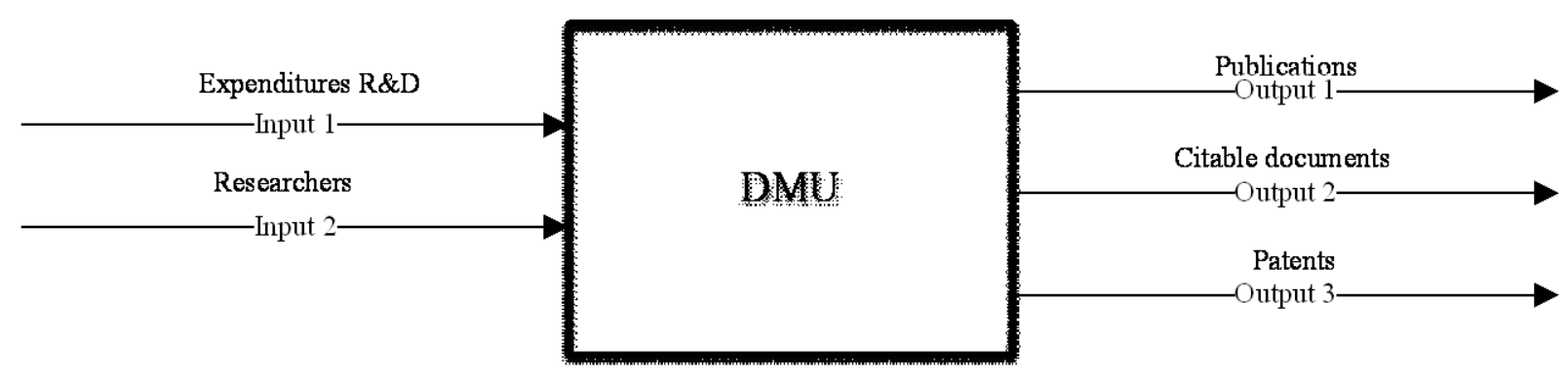

Source: Authors

The efficiency of the EU member states was measured by use of the DEA method, in particular the input-oriented model (CCR) based on the objective function maximizing three weighted outputs. Considering three outputs and two inputs for the evaluation of efficiency, the CCR model can be mathematically defined as:

$$
\begin{aligned}
& \max \theta=\sum_{r=1}^{3} u_{r} \times y_{r 0} \\
& \sum_{i=1}^{2} v_{i} \times x_{i 0}=1 \\
& \sum_{r=1}^{3} u_{r} \times y_{i j}-\sum_{i=1}^{2} v_{i} \times x_{i j} \leq 0, \text { where } j=1, \ldots, 28
\end{aligned}
$$

The input-oriented CCR model enabled the generation of a set of linear equations and inequations, and in the objective function the number of issued publications, cited documents and applications to the EPO in each EU28 country were maximized. The number of DMU production units is 28 , consequently resulting in a set of 28 equations and inequations with the objective function maximizing output, i.e. 28 linear (non-parametric) models (formulated above) with results provided in Table 1. 
Table 1: Results of R\&D efficiency of EU Countries by use of the DEA method in year 2013

\begin{tabular}{|c|c|c|c|c|c|c|c|}
\hline & EU country & $\begin{array}{l}\text { Efficiency } \\
*\end{array}$ & $\begin{array}{l}\text { Input } 1 \\
\text { Expenditures } \\
\text { R\&D }\end{array}$ & $\begin{array}{l}\text { Input } 2 \\
\text { Number of } \\
\text { Researchers }\end{array}$ & $\begin{array}{l}\text { Output } 1 \\
\text { Number of } \\
\text { documents) }\end{array}$ & $\begin{array}{l}\text { Output } 2 \\
\text { Citable } \\
\text { Documents }\end{array}$ & $\begin{array}{l}\text { Output } 3 \\
\text { Patents }\end{array}$ \\
\hline 1 & Austria & 0.829 & 0.340809 & 0.000001 & 0.000000 & 0.000000 & 0.003713 \\
\hline 2 & Belgium & 0.780 & 0.063898 & 0.000018 & 0.000000 & 0.000024 & 0.000788 \\
\hline 3 & Bulgaria & 0.361 & 0.238641 & 0.000069 & 0.000000 & 0.000091 & 0.002943 \\
\hline 4 & Croatia & 0.896 & 0.343701 & 0.000111 & 0.000000 & 0.000149 & 0.000000 \\
\hline 5 & Cyprus & 1.000 & 0.000000 & 0.001135 & 0.000516 & 0.000000 & 0.000000 \\
\hline 6 & Czech Republic & 0.631 & 0.084785 & 0.000024 & 0.000000 & 0.000032 & 0.001046 \\
\hline 7 & Denmark & 0.986 & 0.315074 & 0.000001 & 0.000000 & 0.000000 & 0.003433 \\
\hline 8 & Estonia & 0.361 & 0.332107 & 0.000096 & 0.000000 & 0.000126 & 0.004096 \\
\hline 9 & Finland & 0.807 & 0.290663 & 0.000001 & 0.000000 & 0.000000 & 0.003167 \\
\hline 10 & France & 0.778 & 0.354877 & 0.000001 & 0.000000 & 0.000004 & 0.002889 \\
\hline 11 & Germany & 1.000 & 0.340136 & 0.000000 & 0.000002 & 0.000000 & 0.002549 \\
\hline 12 & Greece & 0.695 & 0.098244 & 0.000032 & 0.000000 & 0.000043 & 0.000000 \\
\hline 13 & Hungary & 0.443 & 0.115854 & 0.000033 & 0.000000 & 0.000044 & 0.001429 \\
\hline 14 & Ireland & 0.830 & 0.155936 & 0.000045 & 0.000054 & 0.000000 & 0.001936 \\
\hline 15 & Italy & 1.000 & 0.482330 & 0.000003 & 0.000000 & 0.000011 & 0.000000 \\
\hline 16 & Latvia & 0.590 & 0.607706 & 0.000175 & 0.000000 & 0.000231 & 0.007495 \\
\hline 17 & Lithuania & 0.359 & 0.292566 & 0.000084 & 0.000000 & 0.000111 & 0.003608 \\
\hline 18 & Luxembourg & 1.000 & 0.000000 & 0.000400 & 0.000000 & 0.000000 & 0.009330 \\
\hline 19 & Malta & 0.451 & 0.000000 & 0.001167 & 0.000476 & 0.000000 & 0.020197 \\
\hline 20 & Netherlands & 1.000 & 0.505051 & 0.000000 & 0.000000 & 0.000000 & 0.004917 \\
\hline 21 & Poland & 0.642 & 0.041924 & 0.000013 & 0.000000 & 0.000018 & 0.000000 \\
\hline 22 & Portugal & 0.162 & 0.735294 & 0.000000 & 0.000000 & 0.000005 & 0.005180 \\
\hline 23 & Romania & 0.963 & 0.157148 & 0.000051 & 0.000000 & 0.000068 & 0.000000 \\
\hline 24 & Slovakia & 0.474 & 0.197806 & 0.000057 & 0.000068 & 0.000000 & 0.002456 \\
\hline 25 & Slovenia & 0.579 & 0.196028 & 0.000057 & 0.000000 & 0.000075 & 0.002418 \\
\hline 26 & Spain & 0.840 & 0.473190 & 0.000003 & 0.000000 & 0.000011 & 0.000000 \\
\hline 27 & Sweden & 0.966 & 0.293495 & 0.000001 & 0.000000 & 0.000000 & 0.003198 \\
\hline 28 & United Kingdom & 1.000 & 0.613497 & 0.000000 & 0.000006 & 0.000000 & 0.000000 \\
\hline
\end{tabular}

Source: Authors' calculation using DEA. ${ }^{*}$ Highest efficiency $=1.0000$. inefficient $=0.0000$

The results of the conducted analysis, which had used the DEA method (Table 1). Table 1 showed that six countries of the EU28 are the most efficient (with a value of 1.000) in terms of the selected R\&D indicators: Cyprus, Germany, Italy, Luxembourg, the Netherlands, and Great Britain. Except for Germany and the Netherlands, these are countries that have not allocated either marked investments in $R \& D$ associated with total $R \& D$ expenditures as one of the main indicators of competitiveness and goals in R\&D according to the Europe 2020 strategy. Results in Table 1 also show that, apart from minor exceptions, the influence of output 1 (the number of publications) fails to have an impact on the increase of efficiency of inefficient unites (countries).

Cyprus holds a specific position among EU countries, producing large output (publications and cited publications) with respect to its small size and quite low input (total expenditure and the number of researchers, in this particular case) compared to other countries with significantly higher input, thereby ranking the country with the highest R\&D efficiency. The question raised in relation to Cyprus as well as other countries is the quality of the output. As piece of already carried out research is showed e.g. Halásková and Bednáŕ (2016), in many countries the number of publications connected to researchers' FTE in R\&D is an approximate indicator of the research-activity efficiency. That is because the number of publications is not indicative of the quality of published results, unlike the number of citations. The number of references to published papers, however, demonstrates the importance, significance and relevance of the content for current research. Citations can also indicate the impact that authors have in the 
scientific field. Other authors e.g. Vaněček and Fat'un (2009) argue that assessment focused on one aspect of research (i.e. the volume of publications and their citations) leads to a shift in objectives of research workers, resulting in a large amount of short reports, or artificial citations. Table 1 also provides the countries which fail to have the efficiency quotient that equals 1.000. These countries should increase their efficiency by opting for a more ratio-based use of inputs (number of researchers, in this case). The change to input 1 (expenditure on R\&D) is dependent upon the requirements associated with the target of the Strategy 2020, and should we observe its fulfilment, some countries have been reaching towards it (European Commission, 2016). Results of R\&D efficiency in 2013 (Table 1) also showed that among countries with high efficiency, slightly below 1.000, can also be placed Scandinavian countries, Romania, Spain, Ireland, and Croatia. As our results showed, Scandinavian countries are not among the EU28 countries with the highest efficiency of research (according to the selected input and output). This can be, to some extent, explained by a marked detachment from other member states. These countries have a strong position in $R \& D$, be it total expenditure on $R \& D$, where they are in line with the Europe 2020 strategy, or patent applications. As the results of the present, but also other pieces of research show (e.g. Kozelský 2014), based on the Innovation barometer of EU countries, Scandinavian countries have a strong position in the number of citations of scientific publications, but also other areas of competitiveness. On the basis of the results of R\&D efficiency, these countries fail to reach 1.000, and one form of boosting the efficiency of $\mathrm{R} \& \mathrm{D}$ can be to limit input 2 (the number of researchers).

By contrast, among countries with very a low efficiency are ranked Bulgaria (0.361), Estonia (0.361), Lithuania (0.359) and Portugal (0.162). The resulting ratios of inputs and outputs showed the lowest efficiency in Portugal (Table 1). To make an effective use of inputs and outputs, Portugal has to increase its R\&D efficiency by $43.5 \%$. Due to its input weights, it is advised to increase $R \& D$ expenditures and reduce the number of scientists by 29,000 . As other pieces of research also show (e.g. Kozelský 2014, Jedlička and Machaček 2015), based on results pertaining to innovations of the individual countries (including R\&D indicators) and indicators of competitiveness, Portugal has a good position in the international comparison. Lithuania reaches 0.359 , one of the lowest efficiency rates of $R \& D$. In this case, increase of input 1 should be considered (R\&D expenditures) due to the failure to follow the Europe 2020 target in terms of R\&D. To increase efficiency, however, it should mainly reduce input 2, i.e. number of workers, by 7,630 staff, resulting in efficiency increased by $64.1 \%$ with respect to the outputs observed. As the research shows, Estonia along with Bulgaria share the second lowest R\&D efficiency. The cause of the low efficiency in both cases involves, when compared to other countries, a small number of publication and patent applications to the EPO. Bulgaria's efficiency results are not surprising as it ranks at the bottom in competitiveness and innovation potential. In the case of Estonia, it can be stated that it well realizes its unsatisfactory situation, connected with low investments in R\&D and when confronted with the achieved results, and it is attempting to reach the top of the science-research and technological position of Europe.

The results also showed that the Czech Republic tends to have a rather low R\&D efficiency, amounting to 0.631 , placing it in the group of moderately efficient countries. The Czech Republic reaches R\&D efficiency of $63.1 \%$ (see Table 1), reaching 14th place among the EU countries. To increase its R\&D efficiency by $36.9 \%$, it will have to focus on increasing R\&D expenditures, mainly from private resources, in line with the Europe 2020 strategy, and on decreasing inputs (researchers) by almost a half (15,375 staff) or on boosting their productivity. Reasons for this inefficiency are found not only among inputs (i.e. labour force - researchers but also allocated expenditures on R\&D but also the volume and quality of outputs. This fact is supported also by an analysis of the countries of the EU Innovation barometer Erste Corporate 
Banking 2015, which focused on R\&D indicators stating that almost $2 \%$ of GDP are allocated to R\&D, placing the Czech Republic 10th in the EU (Jedlička and Macháček 2015). Thus there is an adequate amount of investment in $R \& D$, which, however, fails to correspond with the achieved results. In patents, the Czech Republic lags significantly behind the EU average. Conversely, it has a sound position in publications (the article-writing rate above the EU average).

During the evaluation of $R \& D$ results (the number of papers) the quality of the papers was also considered, which is connected with the rate of citing, but also the H-index (Hirsch index is a comprehensive indicator of citing rate in journals listed in the database Web of Science and Scopus). Results of R\&D efficiency in EU countries in 2013, after the H-index was added (2 inputs and 4 outputs), compared to 2012, are seen in Figure 2.

Figure 2: R\&D efficiency in EU countries with an added output (H-index) by use of the DEA method

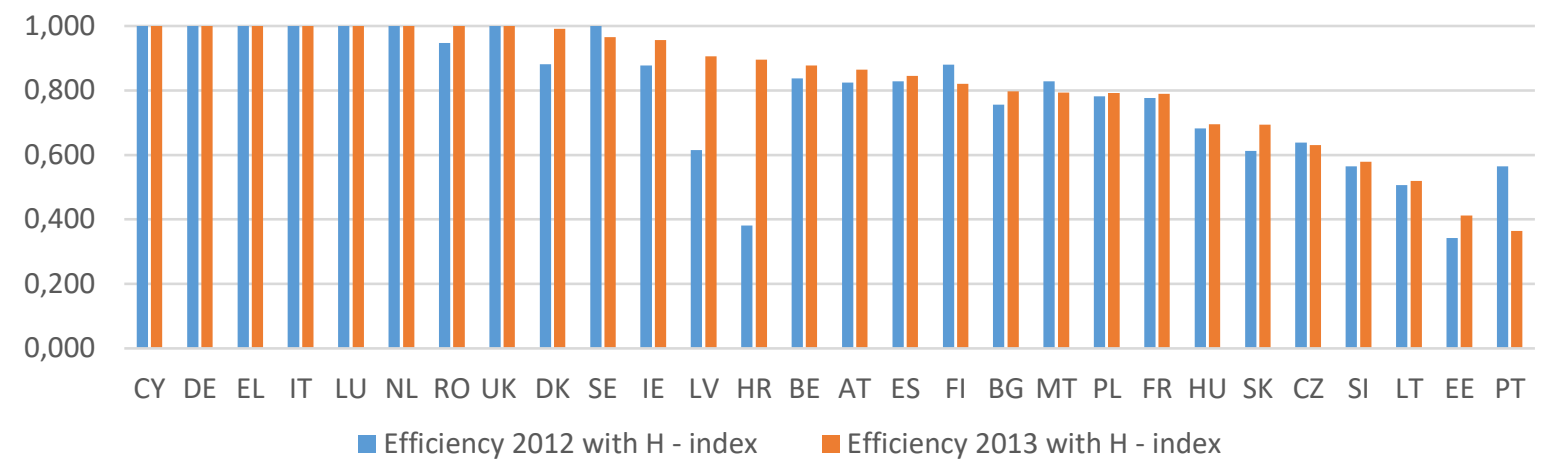

Source: Authors' calculation note: Highest efficiency $=1.0000 ;$ inefficient $=0.0000$

Figure 2 demonstrates that both in 2012 and 2013 eight countries reached the efficiency-rate of 1.000. The comparison of R\&D efficiency in EU countries showed that most countries saw a rise in R\&D efficiency in 2013, compared to 2012. Increase in R\&D efficiency (apart from the value of 1.000) was seen in Greece in 2013, compared to 2012. By contrast, Sweden, which reached R\&D efficiency of 1.000 in 2012, slightly decreased in its position among the evaluated countries in 2013. The lowest R\&D efficiency in 2012 is seen in Estonia (0.342) and Croatia (0.381); in 2013, these rates are seen in Estonia (0.412) and Portugal (0.364). The steepest rise in R\&D efficiency in 2013 is observed in Croatia (by 51\%) and Latvia (by 29\%), compared to 2012. Conversely, Portugal saw a decline in the total R\&D efficiency in 2013 (by 20\%) against 2012.

The outcome of the comparison of R\&D efficiency in EU countries in 2013, based on two inputs and three outputs, found six countries to be the most efficient (reaching the value of 1.000). After increasing the number of inputs, by including the H-index (resulting in two inputs and four outputs), eight countries were evaluated as the most efficient (reaching 1.000). Further, the results showed that after including the $\mathrm{H}$-index, $\mathrm{R} \& \mathrm{D}$ efficiency increased in most countries (in Greece and Romania reaching 1.000). In Croatia, Czech Republic, and Sweden, results of R\&D efficiency remained unchanged even after the I-index was included. Based on the results, it can be said that differences between R\&D efficiency in the countries are associated with the causes for inefficiency of the public sector and the shortage of financial resources, which is an objective limitation in innovation and scientific and technological development. The causes for R\&D inefficiency can also be seen in limited abilities and productivity of the labour force, which can partially be explained by little motivation of researchers as well as low remuneration. 
Results from other research also show apparent differences in R\&D efficiency in EU countries. Research by Hudec and Prochádzková (2013), dealing with relative efficiency knowledge innovation processes in $19 \mathrm{EU}$ countries (evaluating similar R\&D indicators as the present research), showed that if a country consumes only a small amount of inputs to produce existing outputs, it can achieve higher relative efficiency than a country generating more outputs, but at a higher level of inputs. One part of the results showed that V4 countries, when compared with other countries, reach a satisfactory R\&D efficiency when using a lower number of inputs. Aristovnik (2014) evaluates efficiency in the EU27 at the level of NUTS 2 region. The empirical results show that regions with a high intensity of $R \& D$ activities are the most efficient performers. Results from another study, by Cullmann, Schmidt-Ehmcke and Zloczysti (2009), deals with R\&D efficiency in 30 OECD countries, using the DEA method and applying similar R\&D indicators as the present research, show that Germany and Sweden are the most efficient countries in comparison to Mexico and China, which are evaluated as countries with low R\&D efficiency.

\subsection{Evaluation of $R \& D$ indicators in $E U$ countries using correlation analysis}

The inputs and outputs selected for the evaluation of R\&D efficiency in EU countries in 2013 were also evaluated by means of ratio-based indicators with the use of correlation analysis and Pearson correlation coefficient. Similarly, Aristovnik (2014, p. 525) used correlation analysis in evaluating $R \& D$ inputs and outputs in connection with $R \& D$ efficiency in EU countries, using the DEA method. The present R\&D indicators (Figure 3) showed a strong correlation between: 1) the number of researchers and the number of documents $(r=0.960)$, or between the number of researchers and cited documents $(r=0.998)$, and 2) total $R \& D$ expenditure as a percentage of GDP and patent applications to the EPO $(r=0.870)$. A weak correlation of indicators was proved between: 1) total R\&D expenditure as a percentage of GDP and number of documents $(\mathrm{r}=0.288), 2)$ total $\mathrm{R} \& \mathrm{D}$ expenditure as a percentage of GDP and cited documents $(r=0.298)$ and 3$)$ number of researchers and patent applications to the EPO $(r=0.399)$.

Figure 3: Evaluation of R\&D indicators in EU countries using correlation analysis
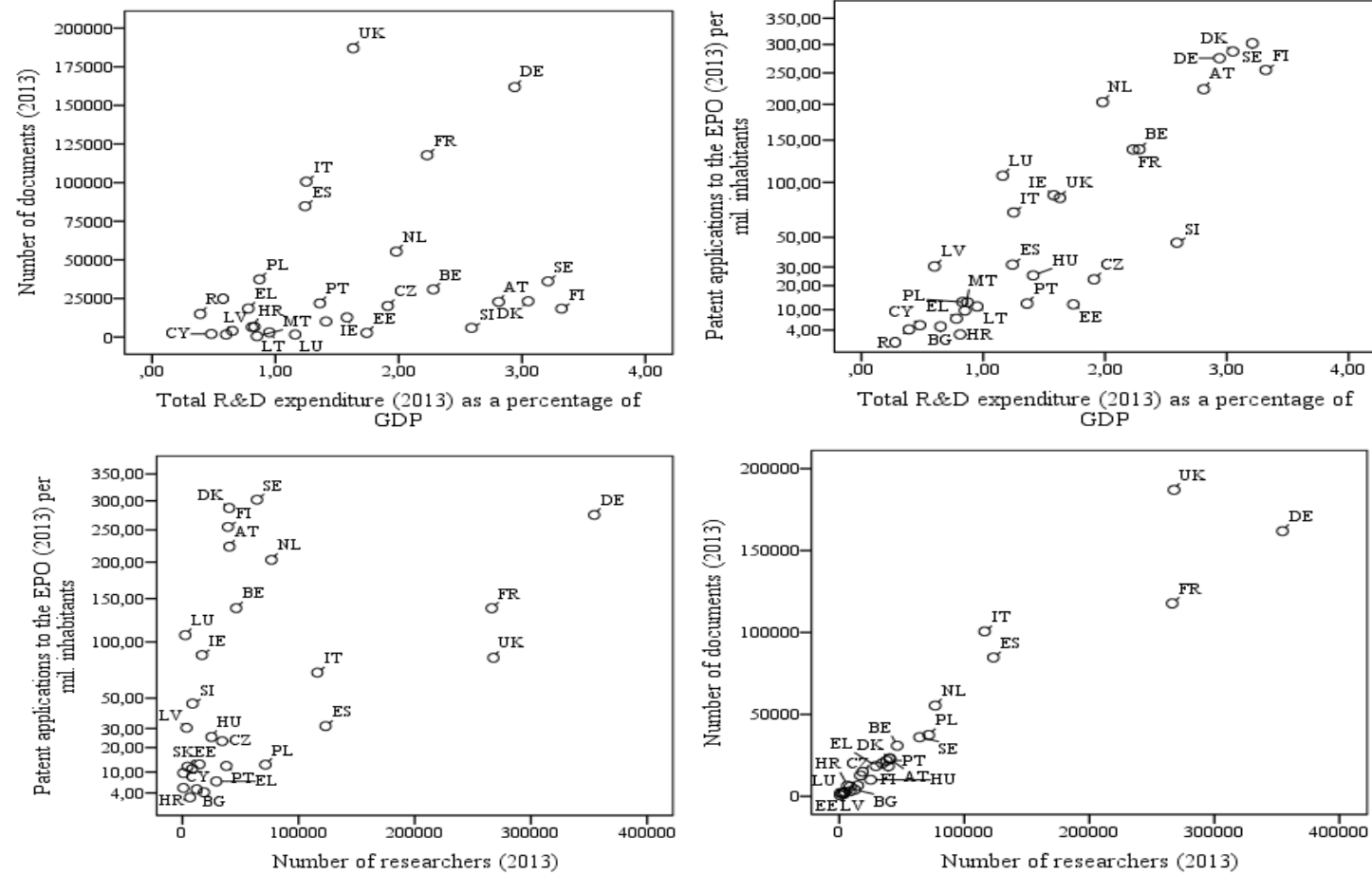

Source: Authors' calculation by using SPSS 
Should the number of papers per researcher be evaluated, a correlation can be observed, with a rising number of papers accompanied with a higher number of researchers. This is confirmed by the example of Germany, United Kingdom, Italy, and the Netherlands, evaluated as R\&D efficient countries by using the DEA method. Luxembourg and Cyprus (as other most evaluated countries in R\&D by the DEA method) confirm that low inputs in the form of the number of papers are accompanied also by low inputs in the number of researchers. The efficient relation is seen on the example of the United Kingdom, which generates a significantly higher number of documents than France with the identical number of researchers. Conversely, Germany with a higher number of researchers generates a lower number of papers in comparison to the UK. The Netherlands shows that with a similar number of researchers as Poland generates a higher number of papers. Similar results were obtained also through the DEA method, when Poland was evaluated as a country with a relatively low R\&D efficiency and the Netherlands as the most R\&D efficient country. Low outputs (number of documents) in relation to low inputs (number of researchers) are confirmed also in other countries evaluated as R\&D less effective by the DEA method.

From the relation between the number of researchers and the number of patent applications to the EPO it can be said that Scandinavian countries, Austria and the Netherlands generate a high number of patent applications to the EPO with a low number of researchers. Another relation of rational indicators can be observed in Germany and Scandinavian countries, which generate an approximately identical amount of submitted patent applications at the EPO, although Germany comprises a several-fold higher number of researchers compared with Scandinavian countries. France generates a higher number of patent applications to the EPO compared to the United Kingdom with an identical number of researchers. In countries evaluated by use of the DEA method as least efficient it can be said that a low number of researchers correlates with a low number of patent applications to the EPO.

Luxembourg and the Netherlands (evaluated by the DEA method as the most efficient) are characterised by a high number of patent applications to the EPO with respect to allocated total R\&D expenditure in comparison to other countries. Luxembourg generates more patent applications to the EPO with lower total R\&D expenditure than Estonia, Hungary and Portugal. In Scandinavian countries, Austria, and Germany (evaluated as efficient) a correlation can be observed, with high numbers of patent applications to the EPO accompanied by high R\&D expenditure. Most countries with low total $R \& D$ expenditures are characterised by a low number of patent applications to the EPO. A moderately efficient relation of rational indicators between total R\&D expenditure and patent applications to the EPO can be observed in Bulgaria and Estonia (considered moderately efficient by DEA). Bulgaria submits six times lower number of patent applications to the EPO with identical R\&D expenditures as Latvia. Estonia generates less patent applications to the EPO with higher total R\&D expenditures than Hungary, Spain, Latvia, or Portugal. In the case of applications to the EPO, as well as other outputs, their level of difficulty and practical application need be considered, in terms of other outputs the rate of countries involved in international cooperation and other factors.

The United Kingdom demonstrates an efficient relation between the number of documents and total R\&D expenditure, generating 15-fold more papers than Ireland with a similar extent of total R\&D expenditure. Another case in point is Germany, which generates several fold more papers with a similar volume of R\&D expenditure as Austria and Denmark. Scandinavian countries and Austria with respect to the highest total R\&D expenditure over long periods of time generate relatively low outputs (number of papers), compared to other countries. It can be drawn from the results that some countries, despite working with minimum costs 
(economically) or a high productivity, do not have to necessarily work efficiently (effectively) and their products may not be beneficial.

\section{Conclusion}

For the sake of assessing the level of competitiveness in EU countries it is vital to observe not only the features of the national innovation system and the national R\&D strategy, but also their interconnection and efficiency of these relations. Results of scientific and research activities in the individual countries are influenced by the priorities of national R\&D policies, the level of scientific and research activities, the system of management, and mainly the investments in $\mathrm{R} \& \mathrm{D}$, including other resources. R\&D efficiency of a given country is also influenced by its economic development and potential created for an innovative environment. A significant role for most countries is played by the Europe 2020 Strategy as regards R\&D financing (1\% from public resources, $2 \%$ from resources from the private sector) for year 2020, but also the boost of competitiveness and generation of new jobs. Based on the defined target, differences in science-research activities in EU countries were identified. The ratio between results and resources, financial as well as non-financial ones, predetermines their efficiency. Results of the assessment of R\&D efficiency of the EU member states, based on the selected indicators, by use of the DEA method in year 2013, showed that out of 28 EU countries, 14 countries were evaluated as highly efficient (of which six countries reach the value of 1.000), whilst in seven countries low R\&D efficiency was confirmed. The comparison of R\&D efficiency of EU countries in 2013 showed that after including the H-index, R\&D efficiency increase in most countries (up to the level of 1.000 in the case of Greece and Romania). Results of R\&D efficiency remained unchanged (even after including the H-index) in Croatia, Czech Republic, and Sweden. R\&D efficiency of EU countries (including the H-index) in 2013, compared to 2012, showed an increase in most countries. In both years, eight countries were evaluated as efficient (reaching the value of 1.000). Greece saw an increase in R\&D efficiency (reaching 1.000 ) in 2013, as opposed to 2012. By contrast, Sweden, which reached the value of 1.000 in R\&D efficiency in 2012, slightly declined in the position of countries with the best results. From the viewpoint of further research, a number of questions associated with R\&D efficiency in EU countries remain open, which are connected with the observation of efficiency development over time and which can be a topic for further discussion and research.

\section{Acknowledgement}

This paper was supported within Operational Programme Education for Competitiveness (Project No. CZ.1.07/2.3.00/20.0296).

\section{References}

[1] ARISTOVNIK, A., 2014. Efficiency of the R\&D Sector in the EU-27 at the Regional Level: An Application of DEA. Lex localis- Journal of Local Self-Government, 12(3), 519-531. ISSN 1581-5374.

[2] ARISTOVNIK, A., 2012. The relative efficiency of education and R\&D expenditures in the new EU member states. Journal of Business Economics and Management, 13(5), 832848. ISSN 1611-1699.

[3] BECKER, B., 2015. Public R\&D Policies and Private R\&D Investment: A Survey of the Empirical Evidence. Journal of Economic Surveys, 29(5), 917-942. ISSN 1467-6419. 
[4] BOJNEC, S. and I. FERTO, 2014. Research and Development Spending and Export Performance by the Technological Intensity of the Products. Journal of Economics, 62 (10), 1065- 1080. ISSN 1617-7134.

[5] COOPER, W. W., S. L. M. SEIFORD and K. TONE, 2007. Data envelopment analysis. A Comprehensive Text with Models, Applications, References and DEA-Solver Software. 2nd ed. New York: Springer. ISBN 978-0387-45283-8.

[6] CULLMANN, A., J. SCHMIDT-EHMCKE. and P. ZLOCZYSTI, 2009. Innovation R\&D Efficiecy and the Impact of the Regulatory Environment- A two stage Semi- Parametric DEA Approach. [online]. [vid. 20. September 2016]. Available from: http://www.diw.de/documents/publikationen/73/diw_01.c.97907.de/dp883.pdf.

[7] DAVID, P. A., B. H. HALL and A. A. TOOLE, 2000. Is public R\&D a complement or substitute for private R\&D? A review of the econometric evidence. Research Policy, 29 (2000) 497-529. ISSN 0048-7333.

[8] DELANGHE, H., U. MULDUR and L. SOETE, 2009. European Science and Technology Policy. Towards Integration or Fragmentation. Cheltenham, Northampton, MA: Edward Elgar Publishing. ISBN 978184844330.

[9] EKINCI, Y. and R. M. ÖN, 2015. A Review on the comparison of eu countries based on research and development efficiencies. WASET. International Journal of Social, Behavioral, Educational, Economic, Business and Industrial Engineering [online]. 9(7), 2368-2371 [vid. 15. March 2016]. Available:http://waset.org/publications/10002087/areview-on-the-comparison-of-eu-countries-based-on-research-and-developmentefficiencies.

[10] European Commission, 2016. Evropa 2020- Hlavní cíle EU voblasti hospodářského růstu. Výzkum a vývoj [online]. [vid. 15. September 2016]. Available from: http://ec.europa.eu/eurostat/web/europe-2020- Indicators.

[11] European Commission, 2010. Europe 2020. European strategy for smart, sustainable and inclusive growth. [online]. [vid. 10. September 2016]. Available from: http://ec.europa.eu/eu2020/pdf/COMPLET\%20EN\%20BARROSO\%20\%20\%20007\%20 -\%20Europe\%202020\%20-\%20EN\%20version.pdf.

[12] EUROSTAT, 2016. Statistics database [online]. [vid. 15. February 2016]. Available from: http://ec.europa.eu/eurostat/data/database.

[13] HALÁSKOVÁ, M. and R. HALÁSKOVÁ, 2015. Research and Development Expenditure Assessment based on Selected Indicators in the EU Countries. In: E. PASTUSZKOVÁ, Z. CRHOVÁ, J. VYCHYTILOVÁ, B. VYTRHLÍKOVÁ and A. KNÁPKOVÁ, eds. Proceedings of the 7th International Scientific Conference Finance and the Performance of Firms in Science, Education, and Practice. Zlín: Tomas Bata University, pp. 342-357. ISBN 978-80-7454-476-7.

[14] HALÁSKOVÁ, M. and P. BEDNÁŘ, 2016. Approaches to the Assessment of Research and Development in EU countries. In: D. ŠPALKOVÁ and L. MATĚJOVÁ, eds. Proceedings of 20th International Conference Current Trends in Public Sector Research. Brno: Masaryk University, pp. 257-265. ISBN 978-80-210-8082-9.

[15] HAWDON, D., 2003. Efficiency, performance and regulation of the international gas industry - a bootstrap DEA approach. Energy Policy, 31(11), 1167-1178. ISSN 0301-4215. 
[16] HUDEC, O. and M. PROCHÁDZKOVÁ, 2013. The Relative Efficiency of Knowledge Innovation Processes in EU Countries. Studies in Regional Science, 43(1), 145-162. ISSN 1880-6465.

[17] CHARNES A., W. W. COOPER and E. RHODES, 1978. Measuring the efficiency of decision making units. European Journal of Operational Research, 2(1978), 429-444. ISSN 0377-2217.

[18] JABLONSKÝ, J. a M. DLOUHÝ, 2004. Modely hodnocení efektivnosti produkčních jednotek. Praha: Professional Publishing. ISBN 80-86419-49-5.

[19] JEDLIČKA, J. a V. MACHÁČEK, 2015. Inovačni barometr Erste Corporate Banking 2015 [online].[ vid. 30. March 2016]. Available from: http://www.csas.cz/static_internet/cs/Evropska_unie/Specialni_analyzy/Specialni_analyz y/Prilohy/sr_2015_11_inovacni_barometr_ecb_2015.pdf.

[20] KOZELSKÝ, T., 2014. Inovačni barometr Erste Corporate Banking 2014 [online]. [vid. 25. February 2016]. Available from:http://www.csas.cz/banka/nav/o-nas/erste-inovacnibarometr-d00020840.

[21] LEE, H. Y., Y. T. PARK and H. CHOI, 2009. Comparative evaluation of performance of national R\&D programs with heterogeneous objectives: A DEA approach. European Journal of Operational Research, 196 (3), 847-855. ISSN 0377-2217.

[22] OCHRANA, F., 2005. Nákladově užitkové metody ve veřejném sektoru. Praha: Ekopress. ISBN 80-86929-13-2.

[23] ROMAN, M., 2010. Regional effciency of knowledge economy in the new EU countries: The Romanian and Bulgarian case. MPRA Paper No. 23083 [online]. [vid. 20. February 2016]. Available: https://mpra.ub.uni-muenchen.de/23083/1/MPRA_paper_23083.pdf.

[24] SHERMAN, H. D. and J. ZHU, 2006. Service productivity management: Improving service performance using data envelopment analysis (DEA). New York: Springer. ISBN 0-387-33211-1.

[25] STANÍČKOVÁ, M. and L. MELECKÝ, 2012. Assessment of efficiency in Visegrad countries and regions using DEA models. Central European Review of Economic Issues Ekonomická revue, 15(3), 145-156. ISSN 1212-3951.

[26] SJR, 2016. Scimago Journal \& Country Rank [online]. [vid. 15. February 2016]. Available from: http://www.scimagojr.com/countryrank.php.

[27] TOLOO, M., 2015. Data Envelopment Analysis. Ostrava: VŠB-TU Ostrava. ISBN 97880-248-3738-3.

[28] VANĚČEK, J. and M. FAŤUN, 2009. Comparison of selected methods of R\&D evaluation in developed countries. Ergo, 4(2), 17-20. ISSN 1802-2170.

[29] VINCOVA, K., 2005. Using DEA models to measure efficiency. Biatec, 13(8), 24-28. ISSN 1335-0900.

[30] WAGNER, J., 2009. Měrení výkonnosti. Jak měřit, vyhodnocovat a využivat informace o podnikové výkonnosti. Praha: Grada Publishing. ISBN 978-80-247-2924-4.

[31] SZAROWSKÁ, I., 2016. Impact of Public R\&D Expenditure on Economic Growth in Selected EU Countries. In: The 9th International Scientific Conference Business and Management 2016. Vilnius: Vilnius Gediminas Technical University. pp. 1-9. ISBN 978609-457-921-9. 